\title{
BONE MINERAL DENSITY AND ACCELEROMETER-DETERMINED HABITUAL PHYSICAL ACTIVITY AND INACTIVITY IN POSTMENOPAUSAL WOMEN
}

\author{
Jana Pelclová, Aleš Gába, Ondřej Kapuš
}

Faculty of Physical Culture, Palacký University, Olomouc, Czech Republic

Submitted in November, 2011

BACKGROUND: In postmenopausal women, physical activity appears to be important in preventing loss of bone mineral density (BMD) and osteoporosis and thus contributes to the reduction of fracture risk.

OBJECTIVE: This cross sectional study aimed to investigate the differences in habitual physical activity, physical inactivity and meeting physical activity recommendations between women with normal femoral BMD and women with osteopenia.

METHODS: Out of the ninety-two postmenopausal women analyzed in this study, $72.8 \%$ women had normal femoral BMD and 27.2\% women were osteopenic. Their BMD and body composition were measured using Dual Energy X-ray Absorptiometry. The region of interest was the total proximal femur. Seven days of physical activity were objectively assessed by using the ActiGraph GT1M accelerometer. Daily activity and inactivity logs were used for the participants to self record their times (minutes) when the accelerometer was worn and follow activity and inactivity patterns.

RESULTS: Women with normal BMD spent significantly more hours/day being active than women with osteopenia. On the other hand, women with osteopenia perform significantly more household related PA. According to the physical inactivity analysis, women with osteopenia spent significantly more minutes/week while doing different mental activities (reading, doing crossword puzzles, etc.) in a sitting position than women with normal BMD.

CONCLUSIONS: In conclusion, the results of this study show the differences in physical activity and physical inactivity in women with different femoral BMD.

Keywords: Osteopenia, dual x-ray absorptiometry, accelerometer, sitting, household related physical activity.

\section{INTRODUCTION}

It was well evidenced that the postmenopausal transition linked with estrogen changes is accompanied by weight gain and often leads to a decline in physical activity (Dubnov \& Berry, 2005). However, particularly in postmenopausal women, physical activity appears to be important in preventing loss of bone mineral density (BMD) and osteoporosis (Warburton, Nicol, \& Bredin, 2006) and thus contributes to the reduction of fracture risk (Nguyen, Sambrook, \& Eisman, 1998).

The relationship between physical activity and mineral bone density has been variously estimated in epidemiological studies (Nguyen, Sambrook, \& Eisman, 1998), cross sectional studies (Coupland et al., 1999; Krumm et al., 2006), and intervention studies (Stengel et al., 2011; Yamazaki et al., 2004). Although the results of the studies were not always consistent, probably due to study design, weight-bearing endurance activities, mainly high intensity, as well as resistance exercise, seem to be effective in maintaining bone mass and hence, in reducing the relative risk for fracture (Kohrt et al., 2004).

Postmenopausal women, as primarily affected by osteopenia/osteoporosis, should be addressed in order to convince them to participate in physical activity, because it helps to stimulate osteoblast activity, decrease the rate of bone loss, and thus substantially reduce the risk of osteoporosis in old age (Warburton et al., 2006). But yet, at the same time, the performed physical activity should be safe and age adjusted. As age increases, the portion of physical inactivity increases as well, and the habitual activities of daily living such as walking, housekeeping, stair climbing, and gardening create a big portion of total daily physical activity.

This cross sectional study aimed to investigate the differences between women with normal BMD and osteopenic women. In habitual physical activity, physical inactivity and meeting physical activity recommendations.

\section{METHODS}

\section{Participants and setting}

One hundred and thirty two healthy ambulatory postmenopausal women were offered free physical activity and BMD analysis within the University of the Third Age program. Ninety-seven women agreed to 
participate and gave their verbal and written consent. Data from five participants had to be excluded due to incomplete physical activity records. Hence, the data of ninety-two women was analyzed in this study. The study was carried out in spring 2010 and 2011 according to the design and methods approved by the Faculty of Physical Culture Ethics Committee at Palacký University, Olomouc. Characteristics of the study subjects involving age, body composition variables, total body and femoral BMD and T-score, and smoking and sport issues are shown in TABLE 1.

\section{MEASUREMENTS}

\section{Bone mineral density and body composition}

BMD and body composition were measured using a Dual X-ray Absorptiometry (DXA) Lunar Prodigy Primo $^{\mathrm{TM}}$ (GE Healthcare, Great Britain). The region of interest was the proximal femur as it is one of the best predictors of hip and other fractures and is technically unaffected by degenerative spinal disease. The DXA device was regularly calibrated before each measurement session using a Lunar phantom. The DXA method shows high validity and reliability in the diagnosis of body composition (Heymsfield et al., 2005). Therefore, we also determined fat free mass $(\mathrm{kg})$ and body fat mass $(\mathrm{kg})$ by means of a total body DXA scan. The fat free mass index (FFMI; $\mathrm{kg} / \mathrm{m}^{2}$ ) and body fat mass index (BFMI; $\mathrm{kg} / \mathrm{m}^{2}$ ) were derived as fat free mass $(\mathrm{kg})$ and body fat mass $(\mathrm{kg})$, respectively, divided by height squared $\left(\mathrm{m}^{2}\right)$. The overall procedure (whole body and femoral scan) took approximately 30 minutes.

\section{Physical activity}

Seven days of physical activity was objectively assessed by using the ActiGraph GT1M accelerometer (Manufacturing Technology Inc., FL, USA). The data were intentionally collected during the moderate Springs of 2010 and 2011, avoiding warm summers and cold winters with icy and snowy surfaces. After the BMD measurement, participants were instructed on how to affix the accelerometer snugly by means of an elastic belt cinched at the mid axillary line of the right hip. Moreover, they were asked to wear the instrument during all waking hours (at least 10 hours a day for a consecutive eight days), with the exception of times used to perform water activities.

Daily activity and inactivity logs were used for participants to self record times (minutes) when the accelerometer was worn and activity (e.g. walking, conditioning activities, gardening, household activities, swimming, cycling) and inactivity patterns (watching TV, working at the computer, sitting while reading, traveling, etc.) within each day of the week. Using manufacture supplied software, the time sampling interval of the accelerometers was set at 1 minute and the step mode was activated. Downloaded counts data were assessed and

\section{TABLE 1}

Characteristics of study subjects grouped by femoral bone density

\begin{tabular}{|c|c|c|c|c|}
\hline & \multicolumn{2}{|c|}{$\begin{array}{c}\text { Normal BMD } \\
n=67\end{array}$} & \multicolumn{2}{|c|}{$\begin{array}{l}\text { Osteopenia } \\
\mathrm{n}=25\end{array}$} \\
\hline & $M$ & $S D$ & $M$ & $S D$ \\
\hline Age & 62.61 & 4.9 & 65.76 & 5.21 \\
\hline YSM & 12.61 & 6.38 & 15.00 & 7.18 \\
\hline Height $(\mathrm{cm})$ & 161.36 & 6.16 & 158.73 & 5.44 \\
\hline Weight (kg) & 70.90 & 9.84 & 65.44 & 14.44 \\
\hline BMI $\left(\mathrm{kg} / \mathrm{m}^{2}\right)$ & 27.23 & 4.11 & 25.97 & 4.97 \\
\hline BFMI $\left(\mathrm{kg} / \mathrm{m}^{2}\right)$ & 10.47 & 3.07 & 9.53 & 3.69 \\
\hline FFMI $\left(\mathrm{kg} / \mathrm{m}^{2}\right)$ & 16.83 & 1.5 & 16.33 & 1.67 \\
\hline Total body BMD $\left(\mathrm{g} / \mathrm{cm}^{2}\right)$ & 1.14 & 0.08 & 1.03 & 0.06 \\
\hline Total body T-score & 0.22 & 0.99 & -1.14 & 0.80 \\
\hline Total femur BMD $\left(\mathrm{g} / \mathrm{cm}^{2}\right)$ & 1.00 & 0.07 & 0.81 & 0.04 \\
\hline \multirow[t]{2}{*}{ Total femur T-score } & -0.10 & 0.69 & -1.55 & 0.32 \\
\hline & $N$ & $\%$ & $N$ & $\%$ \\
\hline Smoking & 2 & 2.99 & 2 & 8 \\
\hline Smoking in the past & 23 & 34.33 & 6 & 24 \\
\hline Sport in the past & 53 & 79.11 & 20 & 80 \\
\hline
\end{tabular}

Legend: YSM - years since menopause, BMI - body mass index, BFMI - body fat mass index, FFMI - fat free mass index, BMD - bone mineral density 
cleaned according to procedures reported by Eslinger et al. (2005).

\section{Other data collection}

All participants completed a questionnaire containing questions on potential risk factors for osteopenia/ osteoporosis including medication, smoking, physical activity in the past and menstrual history.

\section{Data analysis}

BMD at the proximal femur was used as the variable for sample grouping. The T-score of the BMD of the proximal femur was calculated by a scanner software platform. According to the World Health Organization (2003), T-score $\geq-1$ indicates normal BMD, T-score $<-1$ and $>-2.5$ indicates osteopenia, and T-score $\leq-2.5$ indicates osteoporosis. Within this classification, 67 women had normal femoral BMD and osteopenia was indicated in 25 women. No women with osteoporosis were found within the study sample.

The statistical package Statistica 9 (StatSoft, 2009) was used for data analysis with significant levels set at $p<0.05$. As the data was not found to be normally distributed for some variables examined (minutes), in these cases descriptive statistics were presented as medians (Me) and in an interquartile range (IQR). In cases of step based variables, mean (M) and standard deviation (SD) were used as the descriptive statistics and the t-test was used to test the differences in steps/day in days of the week between normal BMD and osteopenia groups. The Mann-Whitney U-test was used to test the differences in physical activity and physical inactivity between the normal BMD group and the osteopenia group. Pearson's chi-square test $\left(\chi^{2}\right)$ was used to evaluate how women in the normal BMD group and in the osteopenia group differ in their frequency of meeting PA recommendations (Haskell et al., 2007; Tudor-Locke \& Bassett, 2004; U. S. Department of Health and Human Services, 2008).

In cases where we used the Mann-Whitney U-test, the Cohen's $d(\mathrm{~d}=2 \times Z / \sqrt{n 1+n 2})$ was calculated as an indicator of effect size (Cortina \& Nouri, 2000). The values of $0.2,0.5$ and 0.8 were interpreted as having a small, medium and/or large effect (McCartney \& Rosenthal, 2000; Thomas \& Nelson, 2001). In case of Pearson's chi-square test, Pearson's ceofficient $\left(r_{\phi}=\sqrt{\chi^{2 / N}}\right.$ was used as an indicator of effect size ( $\mathrm{r}=0.1$ small effect, $\mathrm{r}=0.3$ medium effect, $\mathrm{r}=0.5$ large effect) (McCartney \& Rosenthal, 2000).

\section{RESULTS}

In comparison with European findings (EU Sport Ministers, 2008), the women in this study were predominantly active with an average of 9,943 $\pm 3,623$ steps/day, $8.8 \pm 25$ minutes of vigorous PA a week, $229 \pm 154$ minutes of moderate PA a week and $539 \pm 271$ minutes of light PA a week.

Fig. 1 depicts the differences in average steps/day in days of the week between the normal BMD group and the osteopenia group. Women with normal BMD had a slightly higher number of steps/day than women with osteopenia in six days of the week. However, these differences were not statistically significant.

Fig. 1

Average number of steps/day in days of the week of the study subjects grouped by femoral bone density

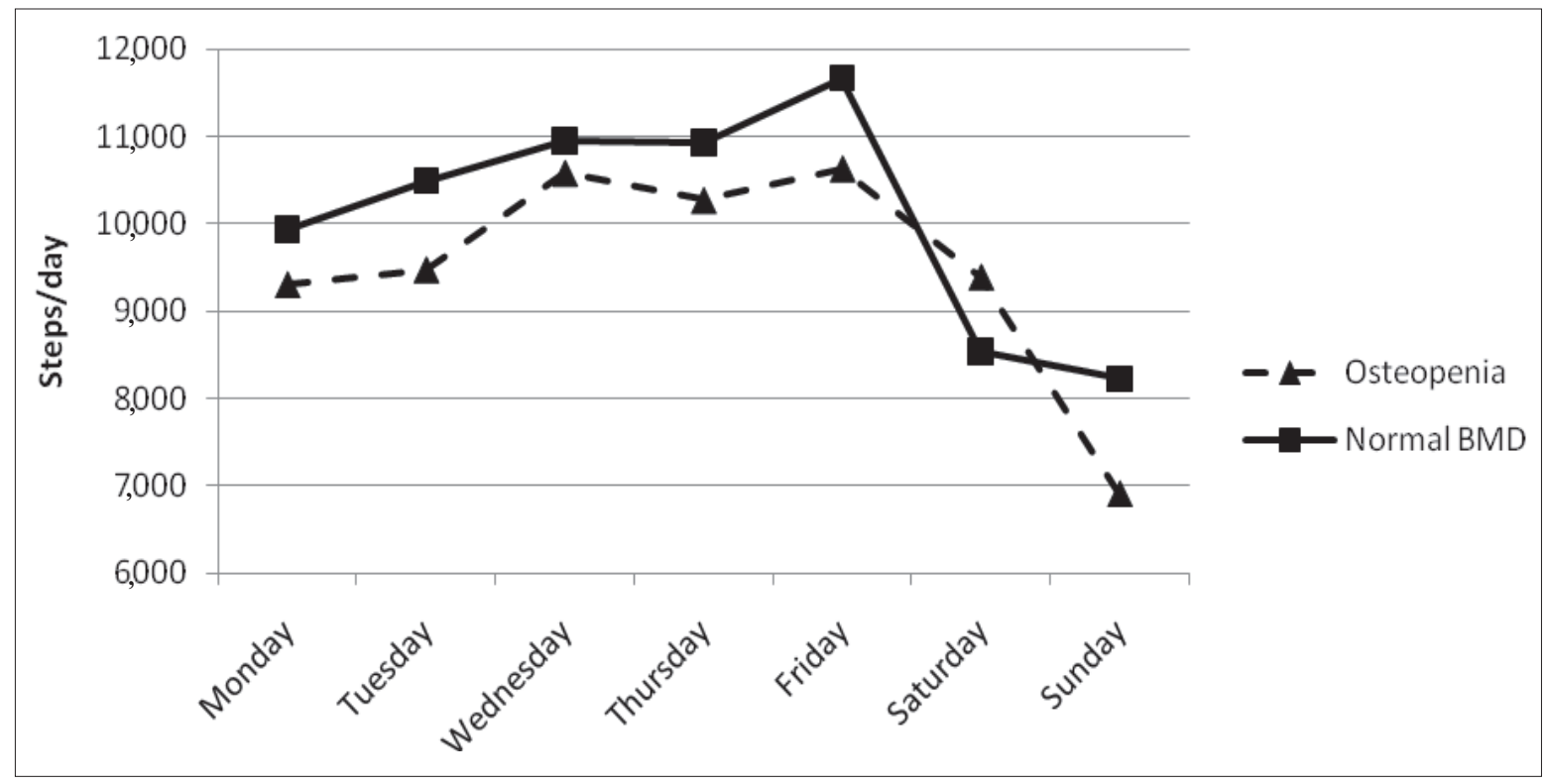


TABLE 2 shows the differences in physical activity and physical inactivity between the group with normal BMD and the osteopenia group. Women with normal BMD spent significantly more hours/day $(p<0.05)$ being active than women with osteopenia. On the other hand, women with osteopenia perform significantly more household related PA ( $\mathrm{p}<0.05)$. No significant differences between the groups were found in relation to any other PA related variables.

When the data were analyzed according to physical inactivity, women with osteopenia spent significantly more minutes/week while doing different mental activities (reading, doing crossword puzzles, etc.) in a sitting position than women with normal BMD. Moreover, the osteopenia group was watching TV by 195 minutes a week more than the normal BMD group. However, this difference was not statistically significant. Both groups spent a similar amount of time while working at the computer or traveling.

No significant differences were found between groups when the data were analyzed according to meeting different PA recommendations (TABLE 3). Nevertheless, the women with normal BMD were more successful in meeting all PA recommendations than women with osteopenia. The main difference was found in meeting the criterion of 10,000 steps/day. Approximately $22 \%$ more women with normal BMD as compared to women with osteopenia met this criterion.

\section{TABLE 2}

Physical activity and inactivity and percentage of meeting PA recommendations of the study subjects grouped by femoral T-score

\begin{tabular}{|c|c|c|c|c|c|c|c|}
\hline \multirow[b]{2}{*}{ Physical activity } & \multicolumn{2}{|c|}{$\begin{array}{c}\text { Normal BMD } \\
\mathrm{n}=67\end{array}$} & \multicolumn{2}{|c|}{$\begin{array}{c}\text { Osteopenia } \\
\text { n }=25\end{array}$} & \multirow[b]{2}{*}{$Z$} & \multirow[b]{2}{*}{$p$} & \multirow[b]{2}{*}{$d$} \\
\hline & $M e$ & $I Q R$ & $M e$ & $I Q R$ & & & \\
\hline Total PA (hour/day) $\dagger$ & 9.11 & 2.53 & 8.38 & 2.05 & $1.96^{*}$ & 0.05 & 0.41 \\
\hline Vigorous PA (min./week) $\dagger$ & 0 & 7 & 0 & 3 & 0.55 & 0.58 & 0.11 \\
\hline Moderate PA (min./week) $\dagger$ & 200 & 242 & 160 & 202 & 1.45 & 0.15 & 0.30 \\
\hline Light PA (min./week) $\dagger$ & 537 & 393 & 430 & 378 & 1.0 & 0.32 & 0.21 \\
\hline Walking (min./week) $\ddagger$ & 450 & 415 & 580 & 300 & 1.17 & 0.24 & 0.24 \\
\hline Resistance and high impact exercises (min./week) $\ddagger$ & 0 & 90 & 20 & 85 & 0.79 & 0.43 & 0.16 \\
\hline Gardening (min./week) $\ddagger$ & 60 & 240 & 90 & 215 & 0.26 & 0.8 & 0.05 \\
\hline Household related PA (min./week) $\ddagger$ & 480 & 430 & 685 & 540 & $1.95^{*}$ & 0.05 & 0.41 \\
\hline Physical inactivity & $M e$ & $I Q R$ & $M e$ & $I Q R$ & $Z$ & $p$ & $d$ \\
\hline Total PI (hour/day) $\dagger$ & 4.98 & 1.83 & 4.7 & 2.8 & 0.68 & 0.5 & 0.14 \\
\hline Watching TV (min./week) $\ddagger$ & 820 & 556 & 1015 & 575 & 1.8 & 0.07 & 0.38 \\
\hline Working on the computer (min./week) $\ddagger$ & 180 & 380 & 180 & 310 & 0.08 & 0.94 & 0.02 \\
\hline Sitting while reading, doing crossword puzzles, etc. (min./week) $\ddagger$ & 290 & 430 & 580 & 580 & 2.91 * & 0.00 & 0.61 \\
\hline Sitting while traveling (car, bus etc.) (min./week) $\ddagger$ & 165 & 220 & 165 & 170 & 0.17 & 0.86 & 0.04 \\
\hline
\end{tabular}

Legend: BMD - bone mineral density, Me - median, IQR - inter-quartile range, PA - physical activity, PI - physical inactivity, $\ddagger-$ questionnaire-based data, $\uparrow-$ accelerometer-based data

\section{TABLE 3}

Percentage of meeting PA recommendations of the study subjects grouped by femoral T-score

\begin{tabular}{|l|c|c|c|c|c|c|c|}
\hline & \multicolumn{2}{|c|}{$\begin{array}{c}\text { Normal BMD } \\
\mathbf{n = 6 7}\end{array}$} & \multicolumn{2}{c|}{$\begin{array}{c}\text { Osteopenia } \\
\mathbf{n = 2 5}\end{array}$} & \multicolumn{2}{|c|}{} \\
\hline Meeting recommendations $\dagger$ & $N$ & $\%$ & $N$ & $\%$ & $\chi 2$ & $p$ & $r_{\Phi}$ \\
\hline 10,000 steps/day & 36 & 53.73 & 8 & 32 & 3.45 & 0.06 & 0.19 \\
\hline $150-300$ min./week of MPA & 44 & 65.67 & 13 & 52 & 1.44 & 0.23 & 0.13 \\
\hline$>300$ min./week of MPA & 22 & 32.84 & 6 & 24 & 0.67 & 0.41 & 0.09 \\
\hline $5 \times 30 \mathrm{~min} /$ week of MPA & 21 & 31.34 & 5 & 20 & 1.16 & 0.28 & 0.11 \\
\hline Any VPA & 29 & 43.28 & 10 & 40 & 0.08 & 0.78 & 0.03 \\
\hline
\end{tabular}

Legend: BMD - bone mineral density, MPA - moderate physical activity, VPA - vigorous physical activity, $\uparrow$ - accelerometer based data 


\section{DISCUSSION}

In this cross sectional, descriptive study, the associations between habitual physical activity and inactivity and femoral BMD were investigated. Out of the study sample, $72.8 \%$ women had normal femoral BMD and osteopenia was indicated in $27.2 \%$ of the women. However, no women with osteoporosis were found. These numbers support the findings that osteopenia is more common than osteoporosis (Khosla \& Melton, 2007) and, moreover, than the majority of fractures occur in the population of patients with osteopenia (Pasco et al., 2006). Within this information framework, an investigation of differences in physical activity and inactivity between women with normal BMD and osteopenia seems to be suitable.

The conclusion to be drawn from the meta-analyses of published studies is that high intensity resistance training as well as mixed loading exercise, combining jogging with other low impact loading activity (stair climbing, walking), or a combination of high or low impact exercise with high magnitude exercise (resistance training) can be effective in preserving bone mass in postmenopausal women (Martyn-St James \& Carroll, 2006, 2011). In this study, only a few women participated in any resistance or high impact exercises and vigorous PA, whereas a majority of the women reported household related physical activity. A similar portion of physical activities was reported by Wasburn et al. (1999) in the Physical Activity Scale for the Elderly (PASE), where approximately $60 \%$ of this questionnaire's points were due to household related activity, whereas only $10 \%$ of the total PASE scores were accounted for by leisure time exercise activity (walking, sports, muscular strength/endurance). We found out no significant differences were found between normal BMD and the osteopenia group in resistance and high impact activities. As for household activity, the osteopenic women reported significantly more minutes than women with normal BMD. However, based on accelerometer data, women with normal BMD had significantly more total physical activity than osteopenic women. These results might suggest, consistent with the above mentioned analysis, that low intensity physical activity (e.g. household activities) has no impact on BMD.

Based on a physical inactivity analysis, the women with osteopenia spent significantly more minutes (almost twice as many) while sitting than women with normal BMD. There is limited evidence about the association between physical inactivity and BMD (Nguyen, Sambrook, \& Eisman, 1998). Nevertheless, the majority of studies concerning inactivity issues have examined the impact of physical inactivity on the risk of hip frac- ture (Gregg, Pereira, \& Caspersen, 2000). There is considerable evidence from epidemiologic studies that physical inactivity is a risk factor for hip fracture (Gregg, Pereira, \& Caspersen, 2000). This risk decreases when physical activity increases and conversely, the risk increases in individuals who became inactive (Feskanich, Willet, \& Colditz, 2002).

Postmenopausal women prefer mainly moderate intensity physical activity and walking (Gába et al., 2009). Several physical activity recommendations based on moderate intensity have been advocated as a target for a healthy lifestyle and, additionally, for more health benefits (Haskell et al., 2007; Tudor-Locke \& Bassett, 2004; U. S. Department of Health and Human Services, 2008). However, the link between these targets and bone health is not clear. Hence, in this study the difference in meeting the above mentioned recommendations among women with different levels of BMD was investigated. A higher, although not significant, percentage in meeting all recommendations was observed in women with normal BMD comparing with women with osteopenia. The most apparent, but not significant, difference was found in meeting the value of 10,000 steps/day. Boyer et al. (2011) suggest that the required step value for women with average body weight $(65.1 \mathrm{~kg})$ to maintain normal BMD (T-score of -1.0) is 4,892 steps/day. However, for lighter women even the value of 10,000 steps/day is insufficient, unless they increase their walking speed. Similarly, other studies reported walking speed as an important factor in femoral BMD (Coupland et al., 1999). However, in this study only volume (steps/day; minutes/day) and frequency were taken under consideration and walking speed was beyond the scope of this study. Nevertheless, based on accelerometer step data, women with normal BMD walked more and more often reached the target of 10,000 steps/day than women with osteopenia. Although the causal relationship between walking and femoral BMD was not examined in this study, the results are consistent with the meta-analysis suggesting the significant positive effect of walking on the preservation of BMD at the femoral neck (Martyn-St James \& Carroll, 2008).

The study has several limitations. The small sample size within two unequal groups and the non random selection of participants do not allow any generalization. Furthermore, this study is only descriptive and semi-longitudinal. Longitudinal studies would be more valuable in investigating the effect of habitual physical activity and inactivity on femoral BMD. While analyzing walking, walking speed was found to be an important factor (Boyer et al., 2011), however it is missing in this study. The above mentioned limitations might be taken under consideration while conducting further studies. 


\section{CONCLUSION}

In conclusion, the results of this study show the differences in physical activity and physical inactivity in women with different levels of femoral BMD. Regardless of the intensity of physical activity, women with normal BMD are significantly more active than women with osteopenia. As for physical inactivity, women with osteopenia spend twice as much time sitting during different leisure time activities.

\section{ACKNOWLEDGEMENT}

The study has been supported by the research grant from the Ministry of Education, Youth and Sports of the Czech Republic (No. MSM 6198959221) "Physical Activity and Inactivity of the Inhabitants of the Czech Republic in the Context of Behavioral Changes" and the research grant IGA (FTK_2010_012, FTK_2011_014).

\section{REFERENCES}

Kohrt, W. M., Bloomfield, S. A., Little, K. D., Nelson, M. E., \& Yingling, V. R. (2004). Physical activity and bone health. Medicine \& Science in Sports \& Exercise, 36(11), 1985-1996.

Boyer, K., Kiratli, B., Andriacchi, T., \& Beaupre, G. (2011). Maintaining femoral bone density in adults: How many steps per day are enough? Osteoporosis International, 1-8.

Cortina, J. M., \& Nouri, H. (2000). Effect size for ANOVA design. Thousand Oaks, CA: Sage publications.

Coupland, C. A. C. et al. (1999). Habitual physical activity and bone mineral density in postmenopausal women in England. International Journal of Epidemiology, 28(2), 241-246.

Dubnov, G., \& Berry, E. (2005). Managing obesity after menopause: The role of physical activity. World Review of Nutrition and Dietetics, 95, 29-34.

Esliger, D. W., Copeland, J. L., Barnes, J. D., \& Tremblay, M. S. (2005). Standardizing and optimizing the use of accelerometer data for free living physical activity monitoring. Journal of Physical Activity and Health, 2(3), 366-383.

EU Sport Ministers. (2008). EU physical activity guidelines. Recommended policy actions in support of health enhancing physical activity. Retrieved 4. 12. 2008 from the World Wide Web: http://ec.europa.eu/sport/library/ doc/c1/pa_guidelines_4th_consolidated_draft_en.pdf

Feskanich, D., Willett, W., \& Colditz, G. (2002). Walking and leisure time activity and risk of hip fracture in postmenopausal women. JAMA: The Journal of the American Medical Association, 288(18), 2300-2306.
Gába, A., Pelclová, J., Přidalová, M., Riegerová, J., Dostálová, I., \& Engelová, L. (2009). The evaluation of body composition in relation to physical activity in 56-73 year old women: A pilot study. Acta Universitatis Palackianae Olomucensis. Gymnica, 39(3), 21-30.

Gregg, E. W., Pereira, M. A., \& Caspersen, C. J. (2000). Physical activity, falls, and fractures among older adults: A review of the epidemiologic evidence. Journal of the American Geriatrics Society, 48(8), 883-893.

Haskell, W. L., Lee, I. M., Pate, R. R., Powell, K. E., Blair, S. N., Franklin, B. A., et al. (2007). Physical activity and public health: Updated recommendation for adults from the American College of Sports Medicine and the American Heart Association. Circulation, 116(9), 1081-1093.

Heymsfield, S., Lohman, T., Wang, Z., \& Going, S. (2005). Human body composition. Champaign, IL: Human Kinetics.

Khosla, S., \& Melton, L. J. (2007). Osteopenia. The New England Journal of Medicine, 356(22), 2293-2300.

Krumm, E. M., Dessieux, O. L., Andrews, P., \& Thompson, D. L. (2006). The relationship between daily steps and body composition in postmenopausal women. Journal of Women's Health, 15(2), 202-210.

Martyn-St James, M., \& Carroll, S. (2006). High intensity resistance training and postmenopausal bone loss: A meta analysis. Osteoporos Int., 17(8), 1225-1240.

Martyn-St James, M., \& Carroll, S. (2008). Meta analysis of walking for preservation of bone mineral density in postmenopausal women. Bone, 43(3), 521-531.

Martyn-St James, M., \& Carroll, S. (2011). A meta analysis of impact exercise on postmenopausal bone loss: The case for mixed loading exercise programmes. British Journal of Sports Medicine, 43(12), 898-908.

McCartney, K., \& Rosenthal, R. (2000). Effect size, practical importance, and social policy for children. Child Development, 71(1), 173-180.

Nguyen, T. V., Sambrook, P. N., \& Eisman, J. A. (1998). Bone loss, physical activity, and weight chase in elderly women: The Dubbo osteoporosis epidemiology study. Journal of bone and mineral research, 13(9), 1458-1467.

Pasco, J. A., Seeman, E., Henry, M. J., Merriman, E. N., Nicholson, G. C., \& Kotowicz, M. A. (2006). The population burden of fractures originates in women with osteopenia, not osteoporosis. Osteoporos Int., 17, 1404-1409.

Thomas, J. R., \& Nelson, J. K. (2001). Research methods in physical activity (4th ed.). Champaign, IL: Human Kinetics.

Tudor-Locke, C., \& Bassett, D. (2004). How many steps/ day are enough? Preliminary pedometer indices for public health. Sports Medicine, 34(1), 1-8.

U. S. Department of Health and Human Services. (2008). 2008 Physical activity guidelines for Ameri- 
cans be active, healthy, and happy! Retrieved 23. 10. 2008 from the World Wide Web: http://purl.access. gpo.gov/GPO/LPS112866

Washburn, R. A., McAuley, E., Katula, J., Mihalko, S. L., \& Boileau, R. A. (1999). The physical activity scale for the elderly (PASE): Evidence for validity. Journal of Clinical Epidemiology, 52(7), 643-651.

Warburton, D. E., Nicol, C. W., \& Bredin, S. S. (2006). Health benefits of physical activity: The evidence. $\mathrm{Ca}$ nadian Medical Association journal, 174(6), 801-809.

World Health Organization. (2003). Prevention and management of osteoporosis: Report of a WHO scientific group. Geneva: World Health Organization.

\section{KOSTNÍ DENZITA A HABITUÁLNÍ POHYBOVÁ AKTIVITA A INAKTIVITA U POSTMENOPAUZÁLNÍCH ŽEN}

(Souhrn anglického textu)

VÝCHODISKA: U postmenopauzálních žen je pohybová aktivita důležitá jako prevence úbytku kostní denzity a osteoporózy a přispívá tak ke snížování rizika zlomenin.

CÍLE: Cílem této průřezové studie bylo zjištění, zda existují rozdíly v habituální pohybové aktivitě, pohybové inaktivitě a v plnění doporučení k pohybové aktivitě mezi ženami s normální femorální denzitou a ženami s osteopenií.

METODIKA: Z 92 žen, jejichž výsledky byly zahrnuty do této studie, bylo v pásmu normálních hodnot T-skóre proximálního femuru 72,8 \% žen a u 27,2 \% žen dosahovaly hodnoty T-skóre osteopenie. Denzitometrické vyšetření proximálního femuru, stejně tak diagnostika vybraných tělesných složek, byla uskutečněna metodou duální rentgenové absorpciometrie (DXA). Sedmidenní pohybová aktivita byla monitorována pomocí přístroje ActiGraph GT1M. Údaje o denních aktivitách a inaktivitách a času, kdy byl přístroj nošen, byly probandy zapisovány do speciálních záznamových archů.

VÝSLEDKY: Ženy s normální femorální denzitou byly celkově pohybově aktivnější než ženy s osteopenií, avšak ženy s osteopenií strávily signifikantně více času aktivitou spojenou s domácností. Z analýzy pohybové inaktivity vyplynulo, že ženy s osteopenií strávily sezením (při čtení, luštění křrižovek apod.) signifikantně více času než ženy s normální kostní denzitou.

ZÁVĚRY: Výsledky této studie prokázaly rozdíly v pohybové aktivitě a inaktivitě mezi ženami s rozdílnou femorální denzitou.

Klíčová slova: osteopenia, duální rentgenová absorpciometrie, akcelerometer, sezení, pohybová aktivita v rámci činností v domácnosti.
Mgr. Jana Pelclová, Ph.D.

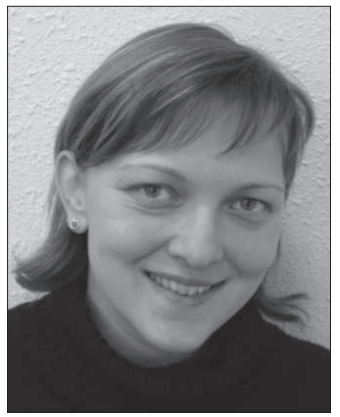

Palacký University, Olomouc

Faculty of Physical Culture

tř. Míru 115

77111 Olomouc

Czech Republic

Education and previous work experience

2005 - Ph.D. in Kinantropology, Dissertation thesis Dance in contemporary system of physical education at schools.

Since 2007 - research and pedagogical assistant at Palacký University, Faculty of Physical Culture, Center for Kinanthropology Research, Olomouc, Czech Republic. Scientific orientation

Research in Kinanthroplogy, focus on monitoring and analysis of the physical activity in children, adolescents, adults and seniors, intervention physical activity programs, physical activity in relation to lifestyles and the environmental attributes.

\section{First-line publications}

Groffik, D., Frömel, K., \& Pelclová, J. (2008). Pedometers as a method for modification of physical activity in students. Journal of Human Kinetics, 20(12), 131-137.

Pelclová, J., El Ansari, W., \& Vašíčková, J. (2010a). Is participation in after school physical activity associated with increased total physical activity? A study of high school pupils in the Czech Republic. International Journal of Environmental Research and Public Health, 7(7), 2853-2865.

Pelclová, J., El Ansari, W., \& Vašíčková, J. (2010b). Study of day, month and season pedometer determined variability of physical activity of high school pupils in the Czech Republic. Journal of Sport Science and Medicine, 9(3), 490-498.

Skalik, K., Frömel, K., Stelzer, J., Pelclová, J., \& Groffik, D. (2009). The influence of increased intensity levels on the attitude of high school females towards aerobic dance lessons. Journal of Human Kinetics, 22, 99-106. 